\title{
La socialización como proceso clave en la gestión del conocimiento
}

\section{Socialization as key process in knowledge management}

\section{Editorial de la revista}

Francisco José García-Peñalvo

Departamento de Informática y Automática, Instituto de Ciencias de la Educación, Grupo GRIAL, Director Científico, Editor-In-Chief Education in the Knowledge Society Journal, Universidad de Salamanca, España. fgarcia@usal.es

\section{Resumen}

El editorial de este segundo número del volumen 17, correspondiente al año 2016, está dedicado al proceso de la socialización en la gestión del conocimiento para complementar la sección especial sobre Redes Sociales y Educación.

\section{Palabras clave}

Gestión del conocimiento; Socialización; Aprendizaje social; Redes Sociales

\begin{abstract}
The editorial of this second issue of volume 17 corresponding to 2016, is devoted to socialization process in the knowledge management in order to complement the special section about Social Networks and Education.
\end{abstract}

\section{Keywords}

Knowledge management; Socialization; Social learning; Social Networks

En este segundo número del volumen 17 se incluye una sección especial dedicada a las Redes Sociales aplicadas en el contexto educativo, que ha sido coordinada por la Dra. María Rosa Buxarrais (2016).

Las redes sociales se han convertido en una herramienta cotidiana de la sociedad. Millones de personas en todo el mundo forman parte de varias redes sociales a través de Internet que acaban afectando a varios aspectos de nuestra vida (Amichai-Hamburger \& Vinitzky, 2010). Internet y su capacidad de conexión social han producido cambios profundos en la vida social de sus usuarios (Hamburger \& Ben-Artzi, 2000).

La educación es un proceso inherentemente social (Mora Mora, Signes Pont, De Miguel Casado, \& Gilart Iglesias, 2015) y las redes sociales pueden enriquecer los procesos de enseñanza/aprendizaje a través de las plataformas en las que los usuarios pueden interaccionar entre sí para intercambiar experiencias, problemas, recursos, etc. (Greenhow, 2009), en definitiva conocimiento (Fidalgo-Blanco, Sein-Echaluce Lacleta, García-Peñalvo, \& Pinilla-Martínez, 2015; Fidalgo-Blanco, Sein-Echaluce, \& García-Peñalvo, 2014).

Las redes sociales como recurso educativo son objeto de estudio en la sección especial de este número, pero como complemento a dicho apartado, se va a profundizar en el proceso de la 
socialización en la gestión del conocimiento. El aprendizaje requiere de un proceso de interiorización del conocimiento, es decir, implica una transformación de conocimiento explícito en conocimiento tácito que todo individuo debe aceptar para aprehenderlo y hacerlo suyo. Esta interiorización es lo que permite aprovechar el enorme potencial que se da en las dinámicas de grupo y en el acceso a las ingentes fuentes de información que ofrece Internet. No obstante, es en dichas dinámicas de grupo en las que se da el proceso de socialización, que permite intercambiar y compartir conocimiento tácito entre sus protagonistas (Fidalgo-Blanco, Sein-Echaluce, \& García-Peñalvo, 2015).

Para lograr esta socialización en los medios sociales es necesaria la interacción entre pares y no solo asistir pasivamente a los diálogos de otros o a los recursos compartidos, que no deja de ser una forma perfectamente válida de acceso a la información como fuente de los procesos de combinación e interiorización y que se da, por ejemplo, en la configuración de los entornos personalizados de aprendizaje o PLEs (Personal Learning Environments) (Conde, García-Peñalvo, Alier, Mayol, \& Fernández-Llamas, 2014; Humante-Ramos, García-Peñalvo, \& Conde-González, 2015; Wilson et al., 2007).

La socialización se encuentra en la base de propuestas pedagógicas como el conectivismo (Downes, 2012; Siemens, 2005), de las comunidades de práctica (Wenger, 1998; Wenger \& Snyder, 2000) o de los cursos masivos en abierto de carácter conectivista o cMOOCs (Fidalgo-Blanco, García-Peñalvo, \& Sein-Echaluce Lacleta, 2013; Fidalgo-Blanco, Sein-Echaluce Lacleta, \& García-Peñalvo, 2013; FidalgoBlanco, Sein-Echaluce Lacleta, García-Peñalvo, \& Esteban-Escaño, 2014).

Por otro lado, la socialización es también fundamental, precisamente por ese intercambio y combinación de conocimiento tácito, en los procesos de aprendizaje informal (García-Peñalvo, Colomo-Palacios, \& Lytras, 2012) y en la transferencia entre las dimensiones formal e informal del aprendizaje (García-Peñalvo \& Griffiths, 2014; Griffiths \& García-Peñalvo, 2016), ya sea en contextos académicos (Viegas et al., 2013) o profesionales (García-Peñalvo \& Conde, 2014; Marques et al., 2013) con el objeto de facilitar esa co-creación de conocimiento (García-Peñalvo, Conde, Johnson, \& Alier, 2013; García-Peñalvo, Johnson, Ribeiro Alves, Minovic, \& Conde-González, 2014).

\section{Contenidos del número}

Como se ha avanzado, este segundo número consta de una sección especial sobre Redes Sociales y Educación (Buxarrais, 2016) compuesta por cuatro artículos (Fuentes, Esteban, \& González, 2016; González Martínez, Lleixà Fortuño, \& Espuny Vidal, 2016; Naval, Serrano-Puche, Sádaba, \& Arbués, 2016; Payà Rico, Duart Montoliu, \& Mengual Andrés, 2016).

Además, el número se completa con otros tres artículos regulares. El primer de ellos titulado "El papel de la gestión del director escolar en el programa Mi Compu.Mx" (Glasserman Morales, Gavotto 
Nogales, \& Ramírez Montalvo, 2016) en el que se presenta la experiencia de la implementación del programa Mi Compu.Mx en el estado de Sonora, desde la perspectiva del director escolar y la gestión llevada a cabo en este proceso de innovación educativa.

En el segundo artículo regular Martha Patricia Astudillo Torres (2016) explica la configuración didáctica de las estrategias de enseñanza con Tecnologías de la Información y la Comunicación que diseña y pone en práctica el profesorado de educación superior en su quehacer docente, con el objetivo de facilitar los contenidos curriculares de tres asignaturas pertenecientes a las carreras de Ingeniería civil e Ingeniería ambiental de las dos instituciones de educación superior más importantes del Estado de Chiapas, México.

Por último, en el artículo "Difusión de realidades: Comunidades virtuales presentes en los videojuegos de rol en línea. (Caso Aguabrial-Dofus - Periodo 2012-2013)" (Acevedo Merlano \& Maya Soto, 2016) se presenta un estudio cualitativo sobre el MMORPG Dofus. Los resultados presentados se basan principalmente en la aplicación del método etnográfico y la implementación de herramientas de investigación social como la observación participante y las entrevistas no dirigidas.

Inthis second issue of volume 17 a special section devoted to Social Networks applied to the educational context is included. This special section has been coordinated by Dra. María Rosa Buxarrais (2016).

Social networks have become an everyday tool of society. Millions of people worldwide are part of various social networks through Internet that may affect almost all aspects of our existence (AmichaiHamburger \& Vinitzky, 2010). Internet and its social connectivity have caused deep changes in the social lives of its users (Hamburger \& Ben-Artzi, 2000).

Education is an inherently social process (Mora Mora et al., 2015) and social networks may enrich the teaching and learning processes through the web platforms where users interact among each other to exchange experiences, problems, resources, etc. (Greenhow, 2009), ultimately knowledge (FidalgoBlanco, Sein-Echaluce Lacleta, et al., 2015; Fidalgo-Blanco, Sein-Echaluce, et al., 2014).

Social networks as educational resources are studied in the special section of this issue, but as complement the socialization process will be deeper explored as key component of the knowledge management cycle. Learning requires a knowledge internalization process; this means that learning implies a transformation of explicit knowledge into the tacit knowledge that every person should accept individually in order to apprehend and make it yours. This internalization process is what allows taking advantage of the huge potential that appears in the group dynamics, also in the access to the large information sources that Internet offers. However, it is in these group dynamics in which the socialization process occurs, which allows allows to exchange and share tacit knowledge among its protagonists (Fidalgo-Blanco, Sein-Echaluce, et al., 2015). 
To achieve this socialization in social media is needed the peer interaction and not only be a passive lurker in the dialogs that are born in the social activities or a resource consumer, although these actions are a completely valid way to access the information as source for combination and internalizations processes. This passive approach may appear, for example, in the Personal Learning Environment configuration (Conde et al., 2014; Humante-Ramos et al., 2015; Wilson et al., 2007).

Socialization is in the roots of the pedagogical approaches such as connectivism (Downes, 2012; Siemens, 2005), in the community of practices (Wenger, 1998; Wenger \& Snyder, 2000) or in the massive open courses with a connectivist characteristics, the so called cMOOCs (Fidalgo-Blanco, García-Peñalvo, et al., 2013; Fidalgo-Blanco, Sein-Echaluce Lacleta, et al., 2013; Fidalgo-Blanco, SeinEchaluce Lacleta, et al., 2014).

On the other hand, socialization is also fundamental, due to the tacit knowledge interchange and combination, in all informal learning processes (García-Peñalvo et al., 2012), also in the transfer between formal and informal dimensions of learning (García-Peñalvo \& Griffiths, 2014; Griffiths \& García-Peñalvo, 2016), both in academic contexts (Viegas et al., 2013) or in professional ones (GarcíaPeñalvo \& Conde, 2014; Marques et al., 2013) with the aim of making easy the knowledge co-creation (García-Peñalvo et al., 2013; García-Peñalvo et al., 2014).

\section{Contents of the issue}

As advanced, this second issue contains a special section on Social Networks and Education (Buxarrais, 2016) that is composed by four papers (Fuentes et al., 2016; González Martínez et al., 2016; Naval et al., 2016; Payà Rico et al., 2016).

In addition, the issue is completed with three other regular articles. The first of them is entitled "The managing role of the school principal in Mi Compu.Mx program" (Glasserman Morales et al., 2016) in which the experience of the implementation of Mi Compu Mx program in the state of Sonora (Mexico) is presented from the perspective of the school principal and management carried out in this process of educational innovation.

In the second regular paper Martha Patricia Astudillo Torres (2016) explains the didactic configuration of the teaching with Information and Communications Technologies strategies that faculty design and develop with the aim of facilitating the curricula of three subjects belonging to the careers of Civil Engineering and Environmental Engineering of the two most important institutions of higher education of the state of Chiapas, Mexico.

Finally, in the paper "Diffusion of realities: Virtual communities in the online role-playing game. (Case Dofus Aguabrial-- Period 2012 - 2013)" (Acevedo Merlano \& Maya Soto, 2016) a qualitative study is 
presented about Dofus MMORPG. The presented results are mainly based on the application of the ethnographic method and the implementation of social research tools, such as participant observation and undirected interviews.

\section{Referencias/References}

Acevedo Merlano, A. A., \& Maya Soto, N. (2016). Difusión de realidades: Comunidades virtuales presentes en los videojuegos de rol en línea. (Caso Aguabrial-Dofus - Periodo 2012-2013). Education in the Knowledge Society, 17(2), 133-148. doi: http://dx.doi.org/10.14201/eks2016172133148

Amichai-Hamburger, Y., \& Vinitzky, G. (2010). Social network use and personality. Computers in Human Behavior, 26(6), 1289-1295. doi:http://dx.doi.org/10.1016/j.chb.2010.03.018

Astudillo Torres, M. P. (2016). La configuración didáctica de las estrategias de enseñanza con Tecnologías de la Información y la Comunicación en las prácticas pedagógicas de las ingenierías realizadas en dos instituciones de educación superior mexicanas. Education in the Knowledge Society, 17(2), 109-132. doi: http://dx.doi.org/10.14201/eks2016172109132

Buxarrais, M. R. (2016). Redes Sociales y Educación. Education in the Knowledge Society, 17(2), 15-20. doi: http://dx.doi.org/10.14201/eks20161721520

Conde, M. Á., García-Peñalvo, F. J., Alier, M., Mayol, E., \& Fernández-Llamas, C. (2014). Implementation and design of a service-based framework to integrate personal and institutional learning environments. Science of Computer Programming, 88, 41-53. doi:http://dx.doi.org/10.1016/j.scico.2013.10.012

Downes, S. (2012). Connectivism and Connective Knowledge. Essays on meaning and learning networks http://www.downes.ca/.

Fidalgo-Blanco, Á., García-Peñalvo, F. J., \& Sein-Echaluce Lacleta, M. L. (2013). A methodology proposal for developing adaptive cMOOC. In F. J. García-Peñalvo (Ed.), Proceedings of the First International Conference on Technological Ecosystems for Enhancing Multiculturality (TEEM'13) (pp. 553-558). New York, NY, USA: ACM. doi:http://dx.doi.org/10.1145/2536536.2536621

Fidalgo-Blanco, Á., Sein-Echaluce Lacleta, M. L., \& García-Peñalvo, F. J. (2013). MOOC cooperativo. Una integración entre cMOOC y xMOOC. In Á. Fidalgo Blanco \& M. L. Sein-Echaluce Lacleta (Eds.), Actas del II Congreso Internacional sobre Aprendizaje, Innovación y Competitividad, CINAIC 2013 (Madrid, 6-8 de noviembre de 2013) (pp. 481-486). Madrid, España: Fundación General de la Universidad Politécnica de Madrid. 
Fidalgo-Blanco, Á., Sein-Echaluce Lacleta, M. L., García-Peñalvo, F. J., \& Esteban-Escaño, J. (2014). Improving the MOOC learning outcomes throughout informal learning activities. In F. J. García-Peñalvo (Ed.), Proceedings of the Second International Conference on Technological Ecosystems for Enhancing Multiculturality (TEEM 2014) (Salamanca, Spain, October 1-3, 2014). (pp. 611-617). New York, NY, USA: ACM. doi:http://dx.doi.org/10.1145/2669711.2669963

Fidalgo-Blanco, Á., Sein-Echaluce Lacleta, M. L., García-Peñalvo, F. J., \& Pinilla-Martínez, J. (2015). BRACO: Buscador de Recursos Académicos Colaborativos. In Á. Fidalgo Blanco, M. L. Sein-Echaluce Lacleta, \& F. J. García-Peñalvo (Eds.), La Sociedad del Aprendizaje. Actas del III Congreso Internacional sobre Aprendizaje, Innovación y Competitividad. CINAIC 2015 (14-16 de Octubre de 2015, Madrid, España) (pp. 469-474). Madrid, Spain: Fundación General de la Universidad Politécnica de Madrid.

Fidalgo-Blanco, Á., Sein-Echaluce, M. L., \& García-Peñalvo, F. J. (2014). Knowledge Spirals in Higher Education Teaching Innovation. International Journal of Knowledge Management, 10(4), 16-37. doi:http://dx.doi.org/10.4018/ijkm.2014100102

Fidalgo-Blanco, Á., Sein-Echaluce, M. L., \& García-Peñalvo, F. J. (2015). Epistemological and ontological spirals: From individual experience in educational innovation to the organisational knowledge in the university sector. Program: Electronic library and information systems, 49(3), 266-288. doi:http://dx.doi. org/10.1108/PROG-06-2014-0033

Fuentes, J. L., Esteban, F., \& González, M. R. (2016). Sobre las dimensiones identitarias esenciales del profesorado universitario en el contexto pedagógico-tecnológico contemporáneo. Education in the Knowledge Society, 17(2), 39-54. doi: http://dx.doi.org/10.14201/eks20161723954

García-Peñalvo, F. J., Colomo-Palacios, R., \& Lytras, M. D. (2012). Informal learning in work environments: training with the Social Web in the workplace. Behaviour \& Information Technology, 31(8), 753-755. doi : http://dx.doi.org/10.1080/0144929X.2012.661548

García-Peñalvo, F. J., \& Conde, M. Á. (2014). Using informal learning for business decision making and knowledge management. Journal of Business Research, 67(5), 686-691. doi:http://dx.doi. org/10.1016/j.jbusres.2013.11.028

García-Peñalvo, F. J., Conde, M. Á., Johnson, M., \& Alier, M. (2013). Knowledge Co-Creation Process Based on Informal Learning Competences Tagging and Recognition. International Journal of Human Capital and Information Technology Professionals (IJHCITP), 4(4), 18-30. doi:http://dx.doi.org/10.4018/ ijhcitp.2013100102

García-Peñalvo, F. J., \& Griffiths, D. (2014). Transferring knowledge and experiences from informal to formal learning contexts. In F. J. García-Peñalvo (Ed.), Proceedings of the Second International 
Conference on Technological Ecosystems for Enhancing Multiculturality (TEEM'14) (pp. 569-572). New York, USA: ACM. doi:http://dx.doi.org/10.1145/2669711.2669957

García-Peñalvo, F. J., Johnson, M., Ribeiro Alves, G., Minovic, M., \& Conde-González, M. Á. (2014). Informal learning recognition through a cloud ecosystem. Future Generation Computer Systems, 32, 282-294. doi:http://dx.doi.org/10.1016/j.future.2013.08.004

Glasserman Morales, L. D., Gavotto Nogales, O. I., \& Ramírez Montalvo, N. A. (2016). El papel de la gestión del director escolar en el programa Mi Compu.Mx. Education in the Knowledge Society, 17(2), 91-108. doi: http://dx.doi.org/10.14201/eks201617291108

González Martínez, J., Lleixà Fortuño, M., \& Espuny Vidal, C. (2016). Las redes sociales y la educación superior: las actitudes de los estudiantes universitarios hacia el uso educativo de las redes sociales, de nuevo a examen. Education in the Knowledge Society, 17(2), 21-38. doi:http://dx.doi.org/10.14201/ eks201617221-38

Greenhow, C. (2009). Social scholarship: Applying social networking technologies to research practices. Knowledge Quest, 37(4), 42-47.

Griffiths, D., \& García-Peñalvo, F. J. (2016). Informal learning recognition and management. Computers in Human Behavior, 55A, 501-503. doi: http://dx.doi.org/10.1016/j.chb.2015.10.019

Hamburger, Y. A., \& Ben-Artzi, E. (2000). The relationship between extraversion and neuroticism and the different uses of the Internet. Computers in Human Behavior, 16(4), 441-449. doi:http://dx.doi. org/10.1016/S0747-5632(00)00017-0

Humante-Ramos, P. R., García-Peñalvo, F. J., \& Conde-González, M. Á. (2015). Mobile personal learning environments: conceptualization and structure. In G. R. Alves \& M. C. Felgueiras (Eds.), Proceedings of the Third International Conference on Technological Ecosystems for Enhancing Multiculturality (TEEM'15) (Porto, Portugal, October 7-9, 2015) (pp. 117-123). New York, USA: ACM. doi:http://dx.doi. org/10.1145/2808580.2808599

Marques, M. A., Viegas, M. C., Alves, G. R., Zangrando, V., Galanis, N., Janssen, J., Waszkiewicz, E., Conde, M. Á., \& García-Peñalvo, F. J. (2013). Managing Informal Learning in professional contexts: the learner's perspective. In F. J. García-Peñalvo, M. Á. Conde, \& D. Griffiths (Eds.), Proceedings of the Workshop on Solutions that Enhance Informal Learning Recognition (WEILER 2013). Co-located with 8th European Conference on Technology Enhanced Learning (EC-TEL 2013) (Paphos, Cyprus, September 18, 2013) (pp. 39-47): CEUR Workshop Proceedings.

Mora Mora, H., Signes Pont, M. T., De Miguel Casado, G., \& Gilart Iglesias, V. (2015). Management of social networks in the educational process. Computers in Human Behavior, 51, Part B, 890-895. 
doi:http://dx.doi.org/10.1016/j.chb.2014.11.010

Naval, C., Serrano-Puche, J., Sádaba, C., \& Arbués, E. (2016). Sobre la necesidad de desconectar: Algunos datos y propuestas. Education in the Knowledge Society, 17(2), 73-90. doi:http://dx.doi. org/10.14201/eks20161727390

Payà Rico, A., Duart Montoliu, J. M., \& Mengual Andrés, S. (2016). HistoEdu, redes sociales e historia de la educación: el pasado pedagógico desde el presente educativo. Education in the Knowledge Society, 17(2), 55-72. doi:http://dx.doi.org/10.14201/eks20161725572

Siemens, G. (2005). Connectivism: A learning theory for the digital age. International Journal of Instructional Technology and Distance Learning, 2(1), 3-10.

Viegas, C., Marques, A., Alves, G., Zangrando, V., Galanis, N., Brouns, F., Janssen, J., Waszkiewicz, E., Mykowska, A., Conde González, M. Á., García-Holgado, A., \& García-Peñalvo, F. J. (2013). Using TRAILER tool for Managing Informal Learning in academic and professional contexts: the learners' perspective.InF.J.García-Peñalvo(Ed.),ProceedingsoftheFirstInternationalConferenceonTechnological Ecosystems for Enhancing Multiculturality (TEEM'13). November 14-15, Salamanca, Spain (pp. 529-534). New York, USA: ACM. doi:http://dx.doi.org/10.1145/2536536.2536617

Wenger, E. C. (1998). Communities of Practice: Learning, Meaning, and Identity. New York, NY, USA: Cambridge University Press. doi:http://dx.doi.org/10.1017/CB09780511803932

Wenger, E. C., \& Snyder, W. M. (2000). Communities of Practice: The Organizational Frontier. Harvard Business Review, 78, 139-145.

Wilson, S., Liber, O., Johnson, M., Beauvoir, P., Sharples, P., \& Milligan, C. (2007). Personal Learning Environments: Challenging the dominant design of educational systems. Journal of e-Learning and Knowledge Society, 3(3), 27-38. 